\title{
Sistem Informasi Penjualan Merchandise Berbasis Web Pada PT Come Indonusa Dengan Metode Waterfall
}

\author{
Ibnu Dwi Lesmono ${ }^{1}$, Fahlepi Romadoni ${ }^{2}$ \\ ${ }^{1}$ Manajemen Informatika, AMIK BSI Purwokerto, ${ }^{2}$ Teknik Informatika, AMIK BSI Purwokerto \\ e-mail: ${ }^{1}$ ibnu.idl@bsi.ac.id, fahlepi.fro@bsi.ac.id
}

\begin{abstract}
The development of Computer technology and communication technology has changed the current life order, the widespread use of the internet in all aspects of life including in the world of sales. Doing business by using internet facilities that we often familiar with the concept of E-commerce has become a phenomenon today, companies that sell their products require once a system that supports and provide professional services for customers. E-Commerce is the solution of the problem For that the author tries to design a system of merchandise-based sales information website. Merchandise sales system that is in PT. Come Indonusa is still done manually, ranging from recording transactions to storage of other data related to the payment process up to the making of the report, so as to allow errors in the recording, the inaccuracy of reports made and delays in searching the necessary data on during the process. In making this web application merchandise sales use Waterfall software development model. making the application using PHP as a scripting language and XAMPP as a database of data storage.
\end{abstract}

Keywords: E-commerce, Merchandis, Waterfall, ERD, XAMPP, PHP.

\begin{abstract}
Abstrak - Perkembangan Teknologi komputer dan teknologi komunikasi telah mengubah tatanan kehidupan saat ini, semakin luasnya penggunaan internet di segala aspek kehidupan termasuk didalam dunia penjualan. Berbisnis dengan menggunakan fasilitas internet yang sering kita kenal dengan konsep E-commerce telah menjadi sebuah fenomena saat ini, perusahaan yang yang menjual produknya membutuhkan sekali adanya suatu sistem yang menunjang dan memberikan pelayanan yang profesional bagi para pelanggan. E-Commerce adalah solusi dari permasalahan tersebut Untuk itulah penulis mencoba merancang sebuah sistem informasi penjualan merchandise berbasis website. Sistem penjualan merchandise yang ada pada PT. Come Indonusa ini masih dilakukan secara manual, mulai dari pencatatan transaksi sampai penyimpanan data-data lainnya yang berhubungan dengan proses pembayaran hingga sampai pembuatan laporan, sehingga memungkinkan terjadi kesalahan dalam pencatatan, kurang akuratnya laporan yang dibuat dan keterlambatan dalam pencarian data-data yang diperlukan pada saat proses berlangsung. Pada pembuatan aplikasi web penjualan merchandise ini menggunakan model pengembangan perangkat lunak Waterfall. pembuatan aplikasi menggunakan PHP sebagai bahasa script dan XAMPP sebagai database tempat penyimpanan data.
\end{abstract}

Kata Kunci: E-commerce,Merchandis, Waterfall, ERD, XAMPP, PHP.

\section{A. PENDAHULUAN}

Semakin ketatnya persaingan di dunia bisnis, maka perlu adanya media penjualan dan pengolah data yang dapat memberikan kemudahan, kecepatan dan ketepatan bagi pengguna juga kemudahan kepada konsumen untuk mencari dan mendapatkan suatu produk dengan mudah. Dengan bantuan teknologi informasi yang semakin canggih ini, tentunyadi harapkan dapat meningkatkan laba perusahaan dan menghadapi persaingan dalam pangsa pasar yang dinamis ini. (Lesmono \& Erica, 2018) Melihat perkembangan teknologi yang semakin pesat, serta persaingan usaha yang semakin terlihat, perusahaan dapat memanfaatkan teknologi internet untuk menunjang kegiatan perusahaan dengan membuat dan memaksimalkan website dalam bidang penjualan. Website dapat dijadikan sebagai sarana untuk bertransaksi jual beli barang atau produk yang membuat transaksi penjualan dapat dilakukan dengan waktu relatif singkat walau jarak jauh. Berbelanja online saat ini sudah menjadi gaya hidup. Ini berdampak pada berubahnya pola sistem penjualan dari bertatap langsung menjadi komunikasi melalui dunia maya atau dikenal dengan istilah e-commerce. Hampir semua instansi menggunakan internet dan memiliki website untuk kelancaran bisnisnya. Teknologi internet berdampak cukup besar pada dunia bisnis (e-commerce) dengan dibukanya jalur perdagangan online sangat memudahkan bagi calon konsumen untuk melihat informasi produk, memesan, ataupun melakukan pembayaran. Itu berarti transaksi penjualan secara online mempunyai calon konsumen yang potensial dari seluruh dunia. (Hellyana, 2017). Salah satu cara untuk bisa berkompetisi dalam ketatnya 
persaingan era globalisasi ini adalah dengan cara memanfaatkan informasi teknologi dalam bentuk media internet yang semakin berkembang (Lesmono, 2018) PT. Come Indonusa bergerak di bidang penjualan produk merchandise. Tetapi selama ini penjualan atas produk-produk tersebut masih bersifat manual dan belum tertata dengan rapi, begitu juga dengan laporan penjualannya masih menggunakan input data manual di komputer. Permasalahan yang terjadi perusahaan belum memiliki website yang menampilkan produk-produk yang di jual oleh PT. Come Indonusa sehingga konsumen kurang mengenal dan penjualan produk menjadi kurang maksimal. Agar perusahaan bisa bersaing dalam menjalankan bisnisnya, sebuah website $E$ Commerce bisa menjadi solusi, yang dapat menyediakan informasi yang up-to-date bagi konsumen, dimana konsumen tanpa harus datang ke perusahaan atau pihak perusahaan tanpa harus datang menemui pihak konsumen. Dengan suatu sistem komputer yang berbasis website akan dapat membantu menyelesaikan permasalahan Di PT. Come Indonusa yang awalnya manual menjadi berbasis web. Pengunjung atau pelanggan tidak perlu datang langsung ke kantor PT. Come Indonusa untuk mendapatkan informasi yang dibutuhkan dan untuk bertransaksi memesan produk yang ingin dibeli atau untuk mengetahui harga-harga dan kualitas produk. Oleh karena itu penulis mencoba merancang sebuah website sistem informasi pemesanan produk yang bertujuan untuk membantu memperlancar proses penjualan yang dilakukan. Maksud dari penulisan ini adalah Merubah sistem penjualan yang awalnya manual sehingga menjadi berbasis web pada PT. Come Indonusa. Sehingga dapat memecahkan masalah yang sering dialami PT. Come Indonusa.

\section{TINJAUAN PUSTAKA}

1. Sistem Informasi

Menurut (Tata Sutabri, 2012) "Suatu sistem dapat diartikan sebagai suatu kumpulan atau himpunan dari unsur, komponen, atau variabel yang terorganisir, saling berinteraksi, saling tergantung satu sama lain, dan terpadu". Menurut (Darmawan, Deni, 2013) "Informasi merupakan hasil dari pengolahan data, akan tetapi tidak semua hasil dari pengolahan tersebut bisamenjadi informasi, hasil pengolahan data yang tidak memberikan makna atau arti serta tidak bermanfaat bagi seseorang bukanlah merupakan informasi bagi orang tersebut". Menurut (Darmawan, Deni, 2013) "Sistem informasi merupakan kumpulan dari subsubsistem yang saling berhubungan satu sama lain, dan bekerja sama secara harmonis untuk mencapai satu tujuan, yaitu mengolah data menjadi informasi yang berguna”. Sub-subsistem tersebut merupakan pengelompokan dari beberapa komponen yang lebih kecil, bagaimana mereka berkelompok bergantung pada interpretasi mereka

\section{Internet}

Menurut (Winarno, Edi, Ali, 2015) "Internet sebetulnya singkatan dari kata Interconnected Networking. Networking artinya jaringan, sedang Interconnected berarti saling berkaitan/terkoneksi. Sehingga internet adalah jaringan komputer yang saling terkoneksi".

\section{Website}

Menurut (Madcoms, 2008) "Website adalah sebutan bagi sekelompok halaman web (web page), dan umumnya merupakan bagian dari suatu nama domain (domain name) atau sub domain dalam World Wide Web (WWW) di internet".

\section{E-Commerce}

Menurut (Lesmono, 2015) "E-Commerce atau Electronic Commerce merupakan distribusi, penjualan, pembelian, pemasaran barang dan jasa melalui sistem elektronik seperti internet". ECommerce dapat melibatkan transfer dana elektronik, pertukaran data elektronik, sistem manajemen inventori otomatis, maupun sistem pengumpulan data otomatis.

5. Metode Waterfall

Metode rekayasa peranti lunak yang digunakan peneliti adalah Metode waterfall. Menurut (Pressman, 2012) waterfall adalah model klasik yang bersifat sistematis, berurutan dalam membangun software. Berikut ini ada dua gambaran dari waterfall model. Fase-fase dalam model waterfall menurut referensi Pressman:

\section{a. Communication}

Langkah ini merupakan analisis terhadap kebutuhan software, dan tahap untuk mengadakan pengumpulan data dengan melakukan pertemuan dengan customer, maupun mengumpulkan data-data tambahan baik yang ada di jurnal, artikel, maupun dari internet.

\section{b. Planning}

Proses planning merupakan lanjutan dari proses communication (analysis requirement). Tahapan ini akan menghasilkan dokumen user requirement atau bisa dikatakan sebagai data yang berhubungan dengan keinginan user dalam pembuatan software, termasuk rencana yang akan dilakukan.

\section{c. Modeling}

Proses modeling ini akan menerjemahkan syarat kebutuhan ke sebuah perancangan software yang dapat diperkirakan sebelum dibuat coding. Proses ini berfokus pada rancangan struktur data, arsitektur software, representasi interfiace, dan detail (algoritma) prosedural. Tahapan ini akan menghasilkan dokumen yang disebut software requirement.

d. Construction

Construction merupakan proses membuat kode. Coding atau pengkodean merupakan 
penerjemahan desain dalam bahasa yang bisa dikenali oleh komputer. Programmer akan menerjemahkan transaksi yang diminta oleh user. Tahapan inilah yang merupakan tahapan secara nyata dalam mengerjakan suatu software, artinya penggunaan komputer akan dimaksimalkan dalam tahapan ini. Setelah pengkodean selesai maka akan dilakukan testing terhadap sistem yang telah dibuat tadi. Tujuan testing adalah menemukan kesalahan-kesalahan terhadap sistem tersebut untuk kemudian bisa diperbaiki.

e. Deployment

Tahapan ini bisa dikatakan final dalam pembuatan sebuah software atau sistem. Setelah melakukan analisis, desain dan pengkodean maka sistem yang sudah jadi akan digunakan oleh user. Kemudian software yang telah dibuat harus dilakukan pemeliharaan secara berkala. Kelebihan dari model ini adalah selain karena pengaplikasian menggunakan model ini mudah, kelebihan dari model ini adalah ketika semua kebutuhan sistem dapat didefinisikan secara utuh, eksplisit, dan benar di awal proyek, maka Software Engineering (SE) dapat berjalan dengan baik dan tanpa masalah.

Meskipun seringkali kebutuhan sistem tidak dapat didefinisikan se-eksplisit yang diinginkan, tetapi paling tidak, problem pada kebutuhan sistem di awal proyek lebih ekonomis dalam hal uang (lebih murah), usaha, dan waktu yang terbuang lebih sedikit jika dibandingkan problem yang muncul pada tahap-tahap selanjutnya. Kekurangan yang utama dari model ini adalah kesulitan dalam mengakomodasi perubahan setelah proses dijalani. Fase sebelumnya harus lengkap dan selesai sebelum mengerjakan fase berikutnya. Masalah dengan waterfall :

1. Perubahan sulit dilakukan karena sifatnya yang kaku.

2. Karena sifat kakunya, model ini cocok ketika kebutuhan dikumpulkan secara lengkap sehingga perubahan bisa ditekan sekecil mungkin. Tapi pada kenyataannya jarang sekali konsumen/pengguna yang bisa memberikan kebutuhan secara lengkap, perubahan kebutuhan adalah sesuatu yang wajar terjadi.

3. Waterfall pada umumnya digunakan untuk rekayasa sistem yang besar yaitu dengan proyek yang dikerjakan di beberapa tempat berbeda, dan dibagi menjadi beberapa bagian sub-proyek.

\section{Konsep Dasar Pemrograman}

Pemrograman komputer tidak dapat terlepas dari konsep pemrograman terstruktur. Karena keduaduanya sama-sama memiliki tujuan untuk memecahkan suatu masalah serta membuat mudah suatu pekerjaan tertentu. Menurut Binanto (2009:1) "Program adalah instruksi-instruksi tersendiri yang biasanya disebut source code yang dibuat oleh programmer".

Dalam hal ini penulis membuat pemrograman terstruktur, yang membahas konsep sebagai berikut:

a. Pemrograman Modular

Fungsi dari pemrograman ini adalah untuk mengelompokkan fungsi-fungsi uatama kedalam sebuah modul, dimana tiap-tiap modul memiliki datanya masing-masing dan mampu mengolah datanya sendiri. Modulmodul ini yang akan digunakan oleh program.

1. Top Down Analisis

Top down analisis merupakan salah satu bentuk mekanisme untuk menyelesaikan suatu masalah dimana permasalahan yang ada dipecah atau dibagi menjadi sub masalah yang lebih kecil atau operasi yang lebih sederhana sampai sub masalah tersebutbisa lebih mudah untuk diselesaikan oleh komputer.

\section{Bottom Up}

Bottom up adalah design dengan memfokuskan pada pemasalahan-permasalahan yang lebih kecil sebelum melihat permasalahan yang lebih besar.

\section{Peralatan Pendukung (Tools System)}

Merupakan alat yang digunakan untuk menggambarkan bentuk logika model dari suatu sistem dengan menggunakan simbol-simbol, lambang-lambang, diagram-diagram yang menunjukan secara tepat arti dan fungsinya.Dalam suatu perusahaan atau organisasi tentunya memiliki bagan atau struktur organisasi yang jelas. Tujuannya adalah skema atau program kerja dan bidang-bidang dalam perusahaan atau organisasi tersebut bisa dengan jelas diketahui dan diterapkan sehingga proses kegiatan dalam perusahaan atau organisasi tersebut dapat berjalan lancar guna mencapai tujuan yang diharapkan Pada sistem berjalan ini pelanggan bisa membeli barang dengan cara menghubungi bagian administrasi menanyakan produk yang akan dibeli, jika barang tersedia maka pelanggan membayar produk yang dibeli. Bagian administrasi mengirim barang yang dibeli dengan melampirkan faktur asli didalam produk tersebut sebagai bukti pembelian.

Kebutuhan perangkat lunak adalah kondisi, kriteria, syarat atau kemampuan yang harus dimiliki oleh perangkat lunak untuk memenuhi apa yang disyaratkan atau diinginkan pemakai. Bab ini berisi mengenai segala sesuatu yang dibutuhkan untuk dapat melakukan analisis kebutuhan perangkat lunak (software requirement analysis) 


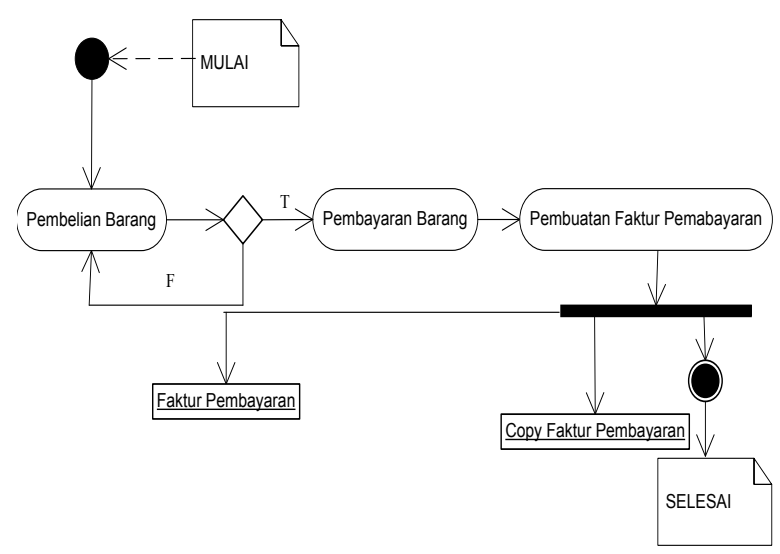

Gambar 1. Activity Diagram Penjualan

\section{METODE PENELITIAN}

Untuk menyelesaikan permasalahan permasalahan yang telah disebutkan sebelumnya maka penulis membuat Sistem Informasi yang nantinya akan dapatmemecahkan permasalahan tersebut. Untuk membuat sistem tersebut penulis menggunakan metode Waterfall untuk menganalisa kebutuhan sistem. Metode air terjun atau yang sering disebut metode waterfall sering dinamakan siklus hidup klasik (classic life cycle), dimana hal ini menggambarkan pendekatan yang sistematis dan juga berurutan pada pengembangan perangkat lunak, dimulai dengan spesifikasikebutuhan pengguna lalu berlanjut melalui tahapan-tahapan perencanaan (planning), permodelan (modeling), konstruksi (construction), serta penyerahan sistem ke para pelanggan/pengguna (deployment), yang diakhiri dengan dukungan pada perangkat lunak lengkap yang dihasilkan (Pressman, 2012).

\section{Tahapan Metode Waterfall}

Dalam pengembangannya metode waterfall memiliki beberapa tahapan yang berurut yaitu: requirement (analisis kebutuhan), design system (desain sistem), Coding (pengkodean) \& Testing (pengujian), Penerapan Program, pemeliharaan.

Tahapan tahapan dari metode waterfall adalah sebagai

berikut :

\section{a) Requirement Analisis}

Tahap ini pengembang sistem diperlukan komunikasi yang bertujuanuntuk memahami perangkat lunak yang

diharapkan oleh pengguna dan batasan perangkat lunak tersebut. Informasi ini biasanya dapat diperoleh melalui wawancara, diskusi atau survei langsung. Informasi dianalisis untuk mendapatkan data yang dibutuhkan oleh pengguna.

\section{b) System Design}

Spesifikasi kebutuhan dari tahap sebelumnya akan dipelajari dalam fase ini dan desain sistem disiapkan. Desain Sistem membantu dalam menentukan perangkat keras (hardware) dan sistem persyaratan dan juga membantu dalam mendefinisikan arsitektur sistem secara keseluruhan.

\section{c) Implementation}

Pada tahap ini, sistem pertama kali dikembangkan di program kecil yang disebut unit, yang terintegrasi dalam tahap selanjutnya. Setiap unit dikembangkan dan diuji untuk fungsionalitas yang disebut sebagai unit testing.

d) Integration \& Testing

Seluruh unit yang dikembangkan dalam tahap implementasi diintegrasikan ke dalam sistem setelah pengujian yang dilakukan masing-masing unit. Setelah

integrasi seluruh sistem diuji untuk mengecek setiap kegagalan maupun kesalahan.

\section{e) Operation \& Maintenance}

Tahap akhir dalam model waterfall. Perangkat lunak yang sudah jadi, dijalankan serta dilakukan pemeliharaan. Pemeliharaan termasukdalam memperbaiki kesalahan yang tidak ditemukan pada langkah sebelumnya. Perbaikan implementasi unit sistem dan peningkatan jasa sistem

sebagai kebutuhan baru.

\section{Kelebihan Metode Waterfall}

Kelebihan menggunakan metode ini (waterfall) adalah metode ini memungkinkan untuk departementalisasi dan kontrol. Proses pengembangan model fase one by one, sehingga meminimalis kesalahan yang mungkin akan terjadi. Pengembangan bergerak dari konsep, yaitu melalui desain, implementasi, pengujian, instalasi, penyelesaian masalah, dan berakhir di operasi dan pemeliharaan.

3. Kelemahan atau Kekurangan Metode Waterfall Kekurangan metode waterfall adalah metode ini tidak memungkinkan untuk banyak revisi jika terjadi kesalahan dalam prosesnya. Karena setelah aplikasi ini dalam tahap pengujian, sulit untuk kembali lagi dan mengubah sesuatu yang tidak terdokumentasi dengan baik dalam tahap konsep sebelumnya.

Pada perancangan sistem informasi ini penulis melakukan Observasi dengan melakukan observasi masalah dengan cara melakukan pengamatan langsung terhadap sistem penjualan yang sedang berjalan yang penjualannya masih manual penulis juga melakukan proses wawancara (interview) dimana penulis mengadakan wawancara langsung dengan bagian yang berhubungan dengan tema penulisan ini, baik bagian administrasi, bagian produksi dan pemimpin perusahaan. teknik pengumpulan data dengan cara mempelajari buku-buku dan literatur-literatur yang berhubungan dengan pembahasan pada penulisan ini, salah satu buku yang digunakan adalah Sistem Informasi Penjualan Berbasis WEB dengan PHP dan MySQL yang digunakan 
sebagai referensi atau bahkan digunakan sebagai bahan pembanding. ruang lingkup pada penelitian ini adalah user dan admin. Dimana user dapat melakukan pendaftaran member atau pelanggan, melakukan transaksi pemesanan dan mendapatkan informasi harga dan unit. Sedangkan admin dapat mengelola data penjualan, data pelanggan, melakukan input data barang, artikel, mengupdate harga baru serta laporan-laporan seperti laporan penjualan, dan laporan pelanggan. Karena alasan tersebut diatas penulis membatasi penulisan ini hanya pada pemakaian aplikasi pembelian melalui website online oleh user yang meliputi halaman beranda, profile, produk, cara pembelian, kategori barang.

\section{HASIL DAN PEMBAHASAN}

Pada bagian ini, dijelaskan hasil penelitian dan pada saat yang sama diberikan pembahasan yang komprehensif. Hasil dapat disajikan dalam angka, diagram, grafik, tabel, dan lain-lain agar dapat dipahami dengan mudah. Mengenai segala sesuatu yang dibutuhkan untuk dapat melakukan analisis kebutuhan perangkat lunak (software requirement analysis). Analisis kebutuhan perangkat lunak (software requirement analysis) merupakan aktivitas awal dari siklus hidup pengembangan perangkat lunak (software). Untuk proyek-proyek perangkat lunak yang besar, analisis kebutuhan dilaksanakan setelah tahap rekayasa sistem atau informasi dan software project planning.

\section{a) Use Case Diagram Belanja Online Halaman} User

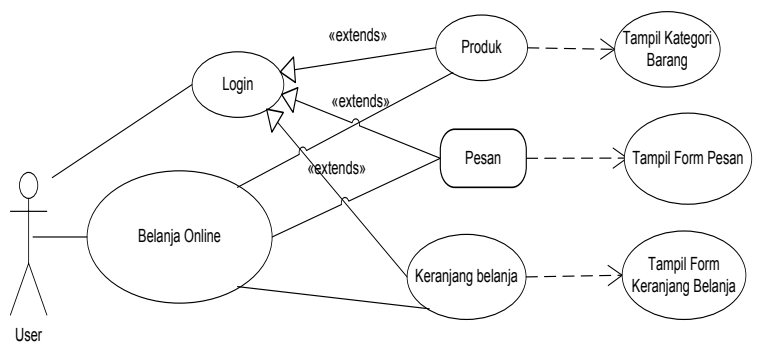

Gambar 2. Use Case Diagram User

\section{b) Activity Diagram}

Activity Diagram menggambarkan berbagai alir aktivitas dalam sistem yang sedang dirancang, bagaimana masing-masing alir berawal, decision yang mungkin terjadi dan bagaimana mereka berakhir.

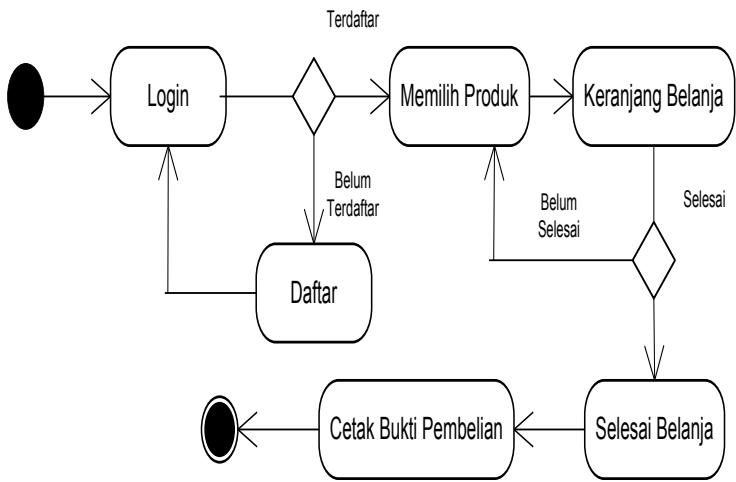

Gambar 3. Activity Diagram penjualan online

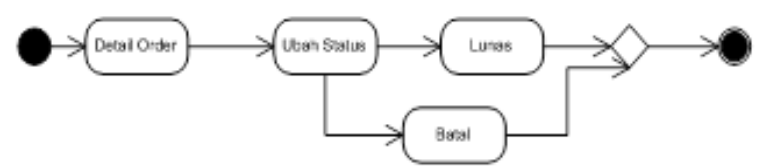

Gambar 4. Activity Diagram Order

\section{c) Entity Relationship Diagram}

Menurut (Herry Utomo, 2010) merupakan tool analisis sistem pertama yang memusatkan pada data dan keterkaitan antar data serta pengorganisasian data".

Adapun komponen-komponen yang digunakan dalam ERD terdiri dari:

\section{Entity}

Entity adalah suatu kumpulan objek atau suatu yang dapat dibedakan atau diidentifikasikan secara unik dengan objek lainnya, dimana semua informasi yang berkaitan dengannya dikumpulkan.

\section{Atribut}

Atribut adalah karakteristik dari entity atau relationship yang menyediakan penjelasan detail tentang entity atau relationship tersebut.

\section{Relationship}

Relationship adalah suatu hubungan yang terjadi antara satu entity dengan entity lainnya atau lebih. Menurut derajatnya, relasi dibagi menjadi tiga macam diantaranya adalah:

a. Unary

Unary adalah sebuah relationship yang terhubung dengan sebuah entity.

b. Binary

Binary adalah sebuah relationship yang menghubungkan dua entity.

c. Tenary

Tenary adalah sebuah relationship yang menghubungkan tiga entity.

Sedangkan ukuran derajat kardinalitas dibagi menjadi tiga macam yaitu:

1. One to One $(1: 1)$

Adalah perbandingan antara entity pertama 
dengan entity kedua berbanding satu banding satu.

2. One to Many (1: M)

Adalah perbandingan antara entity pertama dengan entity kedua berbanding satu banding banyak

3. Many to One (M : 1)

Adalah perbandingan antara entity pertama dengan entity kedua berbanding banyak banding satu.

4. Many to Many (M : M)

Adalah perbandingan antara entity pertama dengan entity kedua berbanding banyak banding banyak.

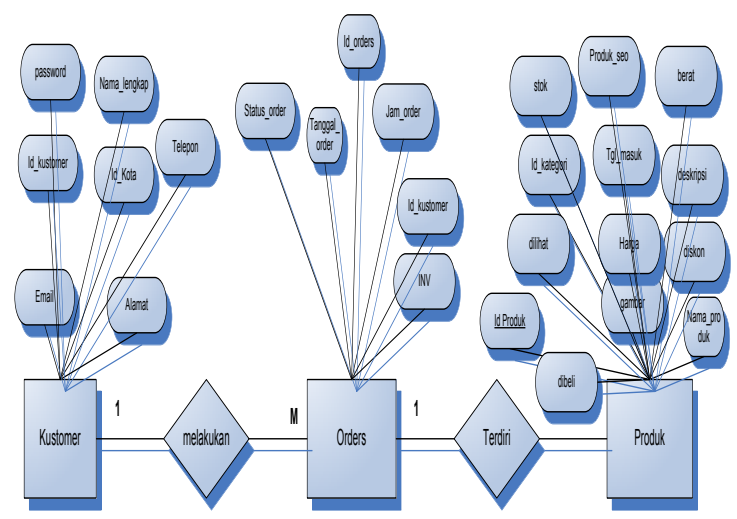

\section{Gambar 5. Entity Realtionship Diagram Database}

\section{d) Component Diagram}

Component Diagram menggambarkan struktur dan hubungan antar komponen perangkat lunak, termasuk ketergantungan diantaranya. Komponen juga dapat berupa interface, yaitu kumpulan layanan yang disediakan sebuah komponen untuk komponen lain, berikut gambar diagramnya.

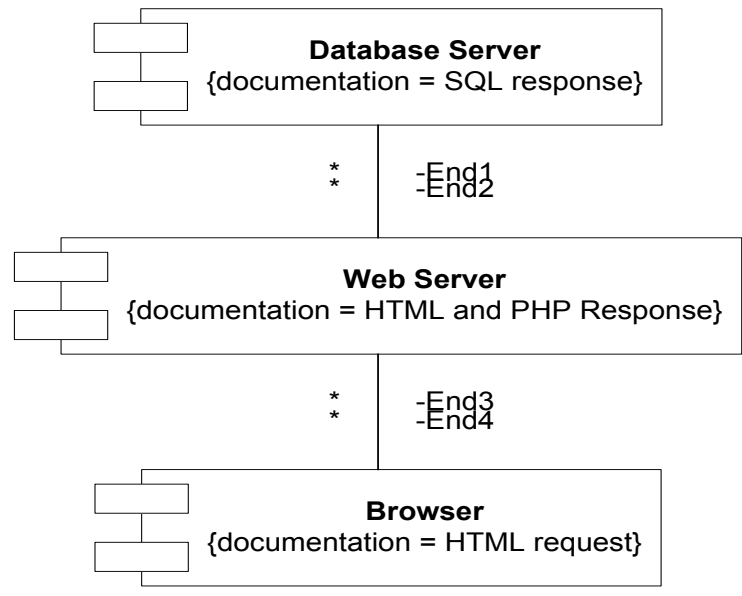

e) Desain Tampilan Web

Desain merupakan bagian terpenting dari sistem. Pada tahap ini akan menjelaskan tentang desain database, desain software architecture dan desain interface. Tampilan User Interface merupakan implementasi dari draft antarmuka situs web yang menampilkan aplikasi kepada User. Sehingga user bisa melakukan pembelian secara online melalui website dalam pembelian Merchandise di PT. Come Indonesia.

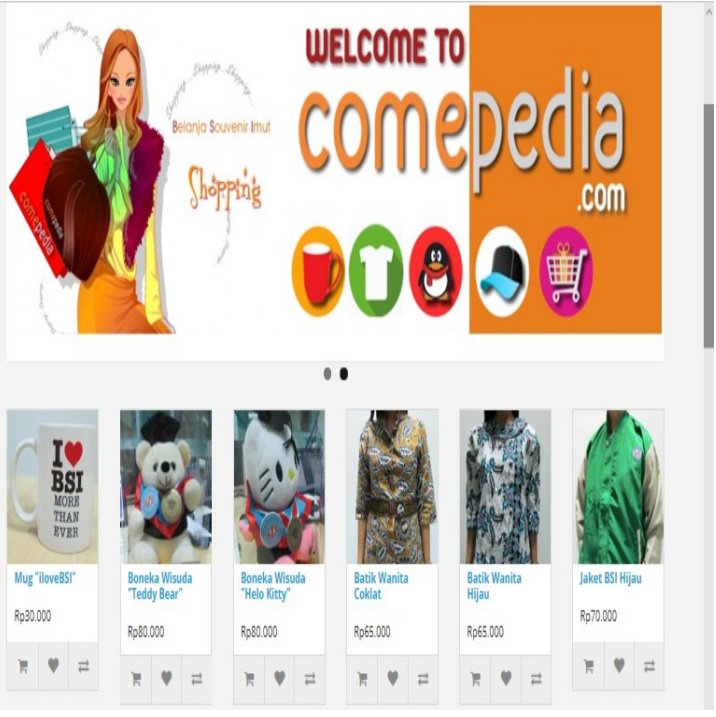

\section{Gambar 7. Tampilan Halaman Depan}

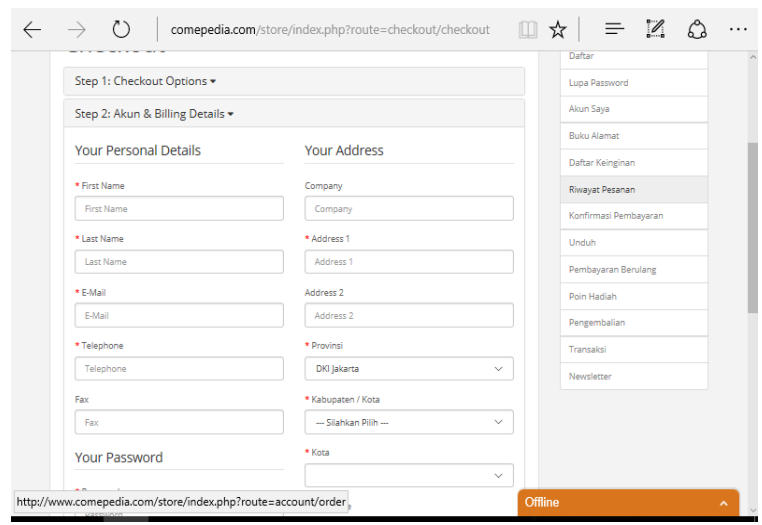

Gambar 8. Tampilan Registrasi Cutomer

Gambar 6. Component Diagram 


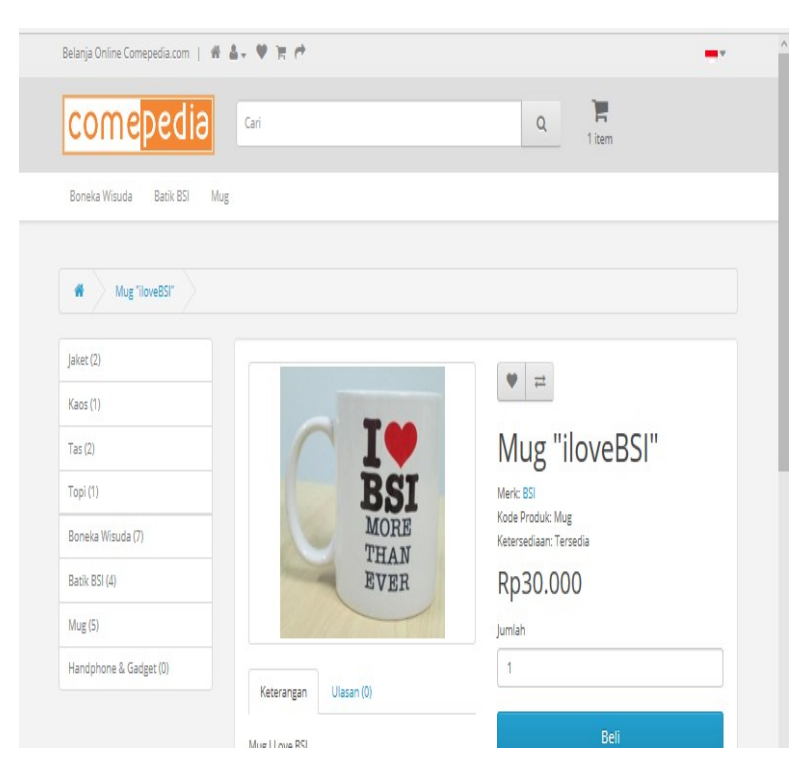

Gambar 9. Tampilan Halaman Transaksi

\section{KESIMPULAN}

Berdasarkan hasil riset yang telah penulis lakukan dalam penyusunan penulisan ini, berikut beberapa kesimpulan yang dapat diambil yaitu dengan adanya sistem penjualan merchandise berbasis web ini, proses penjualan menjadi lebih baik, konsumen dapat melakukan pembelian dengan mudah tanpa harus mendatangi toko, data dan laporan yang sebelumnya bersifat manual dan agak sulit di dapat dengan cepat menjadi lebih mudah dan cepat karena semua data di olah didalam komputer.

Aplikasi yang dibuat bisa mempermudah customer dalam hal mendapatkan informasi produk yang ditawarkan dan juga proses pembelian produk, karena proses yang ada dapat meminimalisir waktu, biaya serta efektifitas proses yang dilakukan dari customer itu sendiri. Saat ini pemrograman aplikasi berbasis web sangat banyak digunakan, PHP dapat dijadikan sebagai salah satu pilihan utama dalam pembuatan aplikasi berbasis web. Penjualan dengan menggunakan media internet sangat efektif jika di bandingkan dengan penjualan yang sifatnya manual.

Selain lebih hemat dalam hal biaya, karena dengan menggunakan web ini mempermudah customer dalam melihat dan membeli produk PT. Come Indonusa. Berdasarkan kesimpulan di atas, maka penulis bermaksud memberikan saran sebagai alternatif pemikiran dengan harapan agar aspek ilmu pengetahuan tidak bersifat statis. Pengembangan website sangat penting, dalam melakukan kegiatan transaksi mulai dari proses order, menyimpan data produk, mengubah data produk serta menghapus data produk sehingga menghasilkan informasi yang cepat, tepat, akurat dan menarik bagi pelanggan. Laman dinamis yang dibuat dengan rancangan yang terencana dengan baik akan menghasilkan laman yang memperjelas dan mempermudah dalam pengolahan data transaksi. Dengan pembuatan laman ini diharapkan dapat mengurangi bahkan mencegah terjadinya pencatatan kegiatan transaksi penjualan yang keliru, data penjualan yang hilang ataupun yang tidak sesuai dengan prosedur. Konsumen Akan mendapatkan Informasi yang $U p$ to Date mengenai merchandise yang baru pada laman website ini.

Adapun saran-saran yang dapat penulis sampaikan adalah Aplikasi web yang telah dibuat dengan database yang telah terkomputerisasi hendaknya dioperasikan secara baik dan selalu diupdate baik dari sisi design maupun keamanan. Pemakai komputer (user), harus lebih mengutamakan pengetahuan tentang teknologi yang berkembang saat ini sehingga aplikasi yang dibuat bisa uptodate sehingga pengunjung tidak bosan. Aplikasi yang dibuat harus mempunyai alur pemrograman yang baik supaya jika aplikasi akan dikembangkan tidak harus mengulang dari awal dan aplikasi yang dibuat bisa lebih optimal.Untuk meningkatkan kinerja serta untuk mengembangkan aplikasi ini maka diharapkan adanya pengembangkan sistem baik dari segi keamanannya maupun dalam design tampilannya.

\section{REFERENSI}

Darmawan, Deni, F. (2013). sistem Informasi Manajemen. Bandung: PT. Remaja Rosdakarya.

Hellyana, C. M. (2017). Sistem informasi penjualan berbasis web, 5(2), 66-73.

Lesmono, I. D. (2015). Pengaruh Penggunaan ECommerce Bagi Pengembangan UKM Dengan Metode TAM, (1), 49-60.

Lesmono, I. D. (2018). Rancang Bangun Sistem Informasi Penjualan Sepatu Berbasis Web, 6(1), 55-62.

Lesmono, I. D., \& Erica, D. (2018). Tata Kelola Teknologi Informasi Dengan Metode COBIT 4.1 (Studi Kasus: PT. IMI). Kajian IImiah, 18(1).

Madcoms. (2008). Teknik Mudah Membangun Website Dengan HTML. Yogyakarta: CV. Andi Offset.

Pressman, R. (2012). Rekayasa Perangkat Lunak. Yogyakarta: CV. Andi Offset.

Tata Sutabri. (2012). konsep sistem informasi. Yogyakarta: CV. Andi Offset.

Winarno, Edi, Ali, Z. (2015). Panduan Lengkap Berinternet. Jakarta: PT. Elex Media Komputindo. 